\title{
Editorial
}

\section{A Mythical Figure, Merits, Interests, and International Anarchy}

\section{Kari Saastamoinen, University of Helsinki}

Two of the four articles in this issue explore the historical character of political concepts in the purpose of challenging widely shared views in contemporary scholarship or bringing new light to political concerns of today. The two other articles offer more theoretically oriented analysis of political rhetoric in cinema and merit-based competition.

In his article Seeing voices: Cinema, Rhetoric and Subjectivity James Martin asks what films can tell us about political rhetoric. He answers this question by analysing how political speeches are presented in cinema, using as his examples two recent films on Winston Churchill. Applying a Lacanian theoretical framework, Martin argues that rhetorical moments in film may activate desire, question fantasy, or to reinvest it. In the two films analysed in the article these moments, in Martin's view, not only restore Churchill as a mythical figure we already think we know but also alter our relationship to the fantasy behind our assumptions concerning this mythical figure.

In her article Merit, Competition, Distinction Heidi Elmgren criticizes ideas of competition and merit she finds at the centre of contemporary job markets and distribution of opportunities. Taking academic competition as her prime example, Elmgren argues that the idea of merit-based competition includes problems which cannot be addressed without altering both conceptual frameworks and institutional practices. Competition founded on the notion of merit not only encourages similarity and establishes hierarchies, but it also fails to recognize what Elmgren calls distinction. By this she refers to something which is relatively non-comparable and independent of prevailing standards, and yet something that can be recognized as excellent and original. At the end of her article Elmgren admits that recognizing such distinction includes problems of its own and would require considerable changes in institutional and societal practises. 
A more historical conceptual analysis in included is Julia Nordblad's article Historicising the Question of Democracy's Presentism: The Concept of Interest and Political Languages of the Future in France. Nordblad addresses the much debated claim, according to which democratic and parliamentary politics have an inherent tendency to prefer the present at the expense of future generations. In Nordblad's view, this claim can be questioned by means of conceptual history, in this case by analysing French parliamentary debates in the 1840's over the best way to take care of nation's forests. Paying particular attention to the rival interpretations of the notion of interest in these debates, Nordblad argues them to show that there is no necessary reason to hold that democratic and parliamentary practices are bound to be indifferent to long-term consequences of their decisions.

Finally, in his article Farewell to Anarchy. The Myth of Anarchy and the Birth of Anarcophilia in International Relations Paul-Erik Korvela addresses the notion of international anarchy in the discipline of international relations. Korvela points out that while authors such as Thukydides, Machiavelli and Hobbes are repeatedly presented as the forerunners of the realist school of international relations and its idea of the anarchical character of inter-state relations, in modern intellectual history these three authors are hardly ever associated with the notion of international anarchy. Even Hobbes, who infamously argued that the condition of human individuals without a common sovereign is that of war, did not characterize the condition between sovereign states as anarchical. Moreover, Korvela argues that the idea of international anarchy is a much more recent innovation than what is customary to think. It was never fully formulated before the end of the 1970s. This means that rather than seeing it as a form of classical wisdom one should analyze it in the context of late twentiethcentury political debates on international relations. 